\title{
A systematic review of the relationship between dystemprament (sue Mizaj) and treatments and management of diseases (Ilaj and Eslah-e-Mizaj)
}

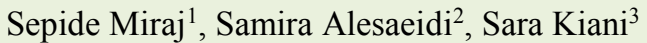

${ }^{1}$ M.D., Gynecologist, Fellowship of Infertility, Assistant Professor, Faculty of Medicine, Shahrekord University of Medical Sciences, Shahrekord, Iran

${ }^{2}$ Rhumatology Research Center, Tehran University of Medical Sciences, Tehran, Iran

${ }^{3}$ Research Assistant, Molecular and Cellular Research Center, Shahrekord University of Medical Sciences, Shahrekord, Iran

\section{Type of article: Systematic review}

\begin{abstract}
Background: Temperament refers to four different humors differentiating in individuals and, as a result, proposes specific therapy for diseases as well as special types of management (avoidance).

Objective: The aim of this study was to overview the relationship between dystemprament and treatment and management of diseases.

Methods: A computerized search of published articles was performed using PubMed, Scopus, Web of Science, and Medline databases as well as local sources from 1965 to 2016. Additional sources were identified through cross-referencing. Original and translated books were also used. Of the whole 105 articles, 40 of them were selected as our database. The search terms used were as follows: temperament, dystemprament, diseases, sue mizaj, treatments, management.

Results: The findings of this study indicated that many remedies are used based on traditional medicine to cure disorders derived from dystemprament such as different kinds of regimen, diet, and drugs. The result of this study shows that regimental therapy contributes to the treatment of some disorders such as muscular dystrophy; Alzheimer's; MS; epilepsy; falij; convulsion; depression; eye diseases; ear disease; mouth, tongue, teeth disease; common cold (nazle); asthma; polyphagia or anorexia; heart diseases; esophagus; peptic ulcer; herpes simplex; liver; colic; jaundice; spleen; kidney and bladder diseases; hemorrhoid; stomach worm; hyperlipidemia. Further, the findings suggest that dietotherapy is beneficial to treat and manage some disease such as sinusitis, lung, asthma, fever, muscular dystrophy, esophagus, peptic ulcer, liver, mouth, tongue, teeth disease, heart disease, polyphagia or anorexia, kidney and bladder diseases, MS, insomnia, piles, acne, permanent ejaculation, anemia, angina and heart attack, sore throat (tonsillitis), osteo-arthritis, rheumatoid arthritis, gout, and impotency.

Conclusion: While traditional medicine contains many useful, less expensive, and even cheap and less risky remedies for lots of morbidities, modern medicine makes them appear nonrelevant. This study gathers some of these remedies to remind one about applying them in our daily lives.
\end{abstract}

Keywords: Dystemprament, Sue mizaj, Temperament, Treatment, Management

\section{Introduction}

Temperament is defined as the quality resulting from reciprocal action of the four contrary principal qualities (hot/cold/moist/dry) $(1,2)$ domiciled within the elements (air, earth, water, fire) $(3,4)$. There are four humors in the body: blood (dam); phlegm (balgham); yellow bile (safra); and black bile (sauda) (5), each of which is associated with a pair of qualities: hot and moist, cold and moist, hot and dry, and cold and dry, respectively. These humors form sanguineous, phlegmatic (serous), bilious (lit. red bile), and melancholic (atrabilious) (lit. black bile) humors (akhlat) in the body $(4,6)$. Each of these temperaments is dominant upon a part of the body: head, chest, kidneys,

\section{Corresponding author:}

Sara Kiani. Molecular and Cellular Research Center, Shahrekord University of Medical Sciences, Shahrekord, Iran. Tel: +98.9140204896, Fax: +98.32225456, Email: kiani.sandra@yahoo.com

Received: July 16, 2016, Accepted: September 18, 2016, Published: December 2016

iThenticate screening: October 09, 2016, English editing: October 21, 2016, Quality control: November 16, 2016

(C) 2016 The Authors. This is an open access article under the terms of the Creative Commons Attribution-NonCommercialNoDerivs License, which permits use and distribution in any medium, provided the original work is properly cited, the use is non-commercial and no modifications or adaptations are made. 
abdomen, etc. Blood is dominant upon the ears, eyes, nose, and brain; phlegm is dominant upon the chest; safra is dominant upon the kidneys; soda is dominant upon abdomen, intestine, gastric $(7,8)$. The dominant temperament is the one that is determined in the person prone to which disease who is diagnosed the unique treatment for that individual (9). There are two types of temperaments: motadil and gheire motadil (out of balance) (10). Each of the four temperaments is intermingled with two qualities: safra (hot and dry), soda (cold and dry) (7), phlegm (cold and moist), blood (hot and moist). Physicians found nine types of temperament in humans: hot, cold, moist, dry, which are single (mofrad) temperaments, and hot and moist, hot and dry, cold and moist, cold and dry, and motadil (compound temperaments) (11). All of these humors exist in each individual's body but given to the point that each individual has a dominant and subdominant temperament (12), one may be phlegmatic-dominant, bilious-dominant, sanguineous-dominant, or melancholic-dominant in the case of temperament $(4,13)$. Sue mezaj or dystemprament is the deficiency and decrease in the physiologic action and reaction of body, in a way that disturbance and dullness happen in its chemical action (11). There are 16 kinds of disorders of temperament (called by names such as sue mizaj, inequable temperament, intemprament, dyscrasias), which cause sue mizaj gheire motadil or imbalance in the body (14). A) The simple types are those deviating from the normal equipoise only regarding to one contrary, including active contrary (hotter than it should be, not moister or drier: hot temperament; colder than it should be, not moister or drier: cold temperament), passive contrary (drier than it should be, but not hotter nor colder: dry temperament; moister than it should be, but not hotter nor colder: moist temperament). B) The compound types are those deviating from the normal equipoise or equability regarding to two contraries at once. Thus, the temperament may be simultaneously hotter and moister than it should be, hotter and drier than it should be, colder and moister than it should be, colder and drier than it should be (4). In addition, there are different classification-related temperaments based on the individual's sex (male, female) (13), age or periods of life [adolescent (up to 30), period of beauty (up to 35 or 40), period of decline (up to 60), senility (60 to the end of life)] (4), seasons (spring, summer, autumn, winter), temperament of different parts of the body (temperament of the eye, liver, brain, heart...) (13), general temperament of individuals (2, 15-18). Besides, temperament of anything entered into the body is of two kinds: hot/cold. Hot gives heat to the body and cold gives coldness to the body (19). Based on the Unani system of medicine, it is believed that a particular illness in the patient has taken place due to disharmony in her/his temperament, which is a departure from its equilibrium status; therefore, the goal of treatment is to remove the disturbance of temperament (20). Treatment is, therefore, aimed directly at restoring balance or equilibrium of various elements, humors and faculties to the patient's temperament or humors $(6,21-23)$. To treat disease, it should be kept in mind that it is fully individualized and relies on the psychophysiological physique of the patient (24). Besides, it is said that "only one drug should not be used to treat one and the same disease" (25). The treatment must include the six factors to ensure that not only are the symptoms treated but the causes of illnesses are also focused upon (26). It is worth mentioning that "While modern medicine aims at controlling symptoms and managing illnesses, Tibb aims at curing illnesses and managing health" (26). It is of high significance that traditional medicine should keep in mind all six factors if its purpose is to cure disease. These six factors are atmospheric air, food and drinks, rest and physical activity, psychological activity, sleep and wakefulness, elimination and retention (25-27). Different ideas about treatment or ilaj were introduced in traditional medicine that are ilaj-bil-Tadbeer (regimental therapy), Ilaj- bil -Ghiza (dietotherapy), Ilaj- bil -Dawa (pharmacotherapy) (28), Ilaj- bil -Yad (surgery) (29). The aim of this study is to overview the relationship between dystemprament (sue Mezaj) and treatment of diseases.

\section{Material and Methods}

\subsection{Design}

This systematic review was carried out from 1965 to 2016 by searching studies in PubMed, Medline, Web of Science, and IranMedex databases. The initial search strategy identified about 119 references. In this study, 48 studies were accepted for further screening and met all our inclusion criteria [in English, full text, dystemprament, diseases, sue mizaj, temperament, treatment, management].

\subsection{Eligibility criteria}

Inclusion criteria included the following keywords used to search for the relevant articles published from August 1930 to June 2016; their full text should be available and in English. Articles included consisted of clinical trials, in vitro, in vivo, review, and meta-analysis studies. Exclusion criteria were abstracts and being not in the timeline of the study. Those articles not matching our inclusion criteria (being in languages other than English and between the timeline of the study) were excluded. 


\subsection{Quality assessment}

To assess the quality of articles, all sections of articles were checked with the STROBE checklist (29). In the screening and selection of article, the presence of inclusion and exclusion criteria also were checked. Based on the search results, 62 articles were identified. Nevertheless, 14 studies were excluded from the review, leaving 48 articles for further analysis.

\section{Results and discussion}

\subsection{Modification of temperament (Eslah-e-mezaj)}

"Ilaj-bil-zid is a medical treatment based on the rule of opposites, i.e., the administration of drugs having contrary actions to etiological changes $(11,30)$, i.e., if a disease results from heat, it must be treated with cold; if from moisture, then with dryness, etc. If the cause is fear or grief, then it must deal with tranquility and confidence; but first the etiology of the disease must be diagnosed (31). To begin treatment, first the habits of that person should be distinguished and their benefits and harms be considered. If it is beneficial, the habits should be changed. A Unani physician discovered that one and every person at the same time may have a hot organ and a cold organ. In this situation, eating both types of foods, i.e., hot and cold foods triggers incidence of diseases (11). The admixture of hot and cold drugs should be boiled and ask the patient to take it in the case that disorder resulted from different temperaments of two organs of body (one is hot and another one is cold). Intake of drug causing these two contradicting states was decreased and gradually improved (11). Avicenna, in his book Canon of Medicine, stated that "Whenever cold and hot drugs were given together, the nature or temperament of the person itself distinguished that where the hotness is required, and where the coldness is requited and guide them to the appropriate place" (4). Whenever the hot and cold temperament becomes dominant, bilious diseases take over. Thus, vomiting and juice of cold and moist fruits are proposed to treat this condition (13). In the case of hot and moist temperament, the treatment is as follow: lots of exercise, taking a bath before meals and after exercise, urinating, gargling, labs, avoidance of tadbeer, which increases hotness and moisture (4). In the case of cold and dry temperament, which is the worst of all among temperaments (in that it is similar to that of elderly), treatments are those tadbeer that increase hotness and moisture (enriched sherbet, message in bath, oil immersion, eat hot and moist and latif meal (4); for cold and moist temperament, treatment consists of lots of exercise, dry food, less sleep and hammam, and oil immersion before hammam.

\subsection{Treatments of diseases}

\subsubsection{Principles of treatment (Usoole ilaj of diseases)}

Unani scholars proposed many kinds of principles. Some of them were placed under the headings of ilaj-bil-tadbeer (regimental therapy); others were of ilaj-bil-ghiza (dietotherapy) or ilaj-bil-dawa (pharmacotherapy) and ilaj bil yad (surgery). These therapies are explained one by one. To treat diseases, the temperament, states of the patient, and his organ should be first examined and the rate of his tolerance should be diagnosed. Thus, it is necessary to first prescribe different kinds of herbal medicine to distinguish his temperament (32-35). Then his body should be purged with drugs that are in harmony with his temperament and will cause the intestines to start to work and gain complete knowledge about liver and kidneys, then find the root of the disease and prescribe the proper drugs and medications (11). Sometimes nature finds a way to remove the toxin or the element of imbalance (11). Sometimes it happens that the form of sue mizaj change (the movement of element [phlegm, blood, bile, black bile], for example, from kidneys to legs) (11). Whenever the physician intends to return the element to the state of balance, he should first soothe the pains, because pain itself attracts the troublesome element. There are general principles of ilaj as follows: 1) whenever the phlegmatic khilt is mixed with blood, the fasd is prioritized; 2) whenever one or two khilt rose, it should be decreased first by eshal then by fasd; 3 ) whenever the safra is dominant, vomiting is prioritized to eshal; 4) in winter, laxatives are better for obese people, while vomiting is better for thin people. In the summer, it is reverse (13): 5) Cold dystemprement is never the reason for pain and disorder, but it is the dry dystemprement that is the cause of disease; 6) Cold and hot temperaments are fundamental, but dry and moist are subsidiary, and the two latter are the consequence of the two first. Thus cold dystemprament is the subsidiary cause of pain because cold temperament involves the organ, and its approximate loss of contiguity (tafarrogh-e ettesal) will happen; thus, this pain is innately due to tafarrogh-e ettesal and secondarily due to cold intemperament (13).

\subsubsection{Ilaj-Bil-Tadbeer (Regimental Therapy)}

Literally, tadbeer is an Arabic word meaning regimen or systemic plan (25). Ilaj bil tadbeer, which is a synonym to panchkarma in Ayurveda (26), is to cure via regimen. It is a method through which care of the sick person and maintenance of general health is performed by means of certain procedures using various tools and equipment (27), i.e., through modulation or modification in asbaabe sitta zarooriya (24); in other words, regimental therapies are mostly nonmedicinal procedures by which we modulate the lifestyle, dietary habits, and habitat of the patient and 
practice some other therapeutic regimens for the treatment of various diseases (25). The regimental therapy includes procedures such as exercise (physical activity) $(36,37)$, diaphoresis, diuresis, Turkish bath, massage, cautery, purgation, emesis, blood-letting in the form of venesection, leech therapy, and cupping with scarification $(28,29,30$, 38). Unani scholars have been practicing this therapy for prophylactic purposes for the maintenance of health as well as for therapeutic purposes for the treatment of diseases since ancient times (24,38-41). Moreover, Ibn Sina has described 36 regimes, including irsale araq (taleeq) (leeching), fasd (Iranian traditional medicine, Tehran University of medical sciences students' attitudes towards it) (venesection), ishal (purgation), qai (emesis), idrar (diuresis), huqna (enema), hijamat (cupping), dalk (massage), riyazat (exercise), hammam (bathing), tareeq (diaphoresis), amle kai (cauterization), nutool (irrigation), inkebaab (inhalation), tanafis (expectoration), takmeed (fomentation), imala (diversion of morbid material), ilam (counter-irritation), aabzan (hydration therapy), zimaadwatila (ointment and liniment), etc. (4).

\subsubsection{Ilaj-Bil-Ghiza (Dietotherapy)}

Ilaj-bil-ghiza (dietotherapy) in Unani medicine has great importance on treating certain diseases by administrating specific diets or by regulating the quality and quantity of food (42). As dietotherapy is the use of food as an agent in effecting recovery from illness, it is concerned with those receiving normal diet as well as those for whom modified diet has been prescribed. Modified diets are the principal therapeutic agents in some metabolic diseases and chronic diseases (27). Diet should be selected that is ghizae lateef, jaiyyadul kaimus, and sariul hazm. Besides, general principles of diet therapy are abstinence (tarke ghiza, fasting), reduction in intake of diet (taqleele giza) (27). Temperament of foods are of four kinds: hot/cold/moist/dry (43). The purpose of dietotherapy is to maintain good nutritional status, to correct deficiencies that may have occurred, and to afford rest to the whole body or to certain organs, which may have been affected as well as to adjust the food intake to the body's ability to metabolize the nutrients and to bring about changes in body weight whenever required. One kind of dietotherapy is tadbir-e-latif, which is eating less instead of doing fasd. In this way, the rest of the food would not return to vessels. As a consequence, less blood will produce, and there is no need to do fasd (11). Before pharmacotherapy, Unani physicians advise restriction or alteration in daily diet, adjusted according to disease, and wait for a few days because some diseases can be cured even with diet. During treatment, specific diets are advised according to disease. 3.2.4. Ilaj-Bil-Dawa (Pharmacotherapy)

Ilaj-bil-dawa (pharmacotherapy) deals with the use of naturally derived drugs that are recommended in conditions when health by natural ways and means such as change in lifestyle does not work (26). The drugs are classified into groups according to their origin, i.e., nabati (plant origin), haiwani (an animal origin), and ma'dni advia (mineral origin) (23). Drugs used may be in single or compound formulation. Temperament has two broad categories: one is concerned with the temperament of humans; the other is about temperament of advia (drugs) (44). Saying that the drug is hot or cold does not mean that the substance of the drug is hot or cold or that its substance is hotter or colder than the human body, but it means that this drug induces heat or cold in the body, exceeding heat or cold of the human body (23). Treatment with drugs, as said by Avicenna, must take into account the following rules: choice of drugs by their quality, selection of drugs by their quantity, and this rule includes change in weight, potency, and properties and the time of administration of drugs (45). Drugs are classified into two kinds: single drugs, compound drugs (31).

Table 1. Treatment proposed via pharmacotherapy (ilj bil dawa)

\begin{tabular}{|c|c|c|}
\hline Disease & Temperament (Mizaj) & Treatment \\
\hline \multirow[t]{2}{*}{ Liver } & Moist & Use astringent drug, decrease hot drug \\
\hline & Dry & Use enriching drug of liver \\
\hline Peptic ulcer & Cold & Cinnamon pill \\
\hline Hypertension & Hot and moist & Hops, hawthorn berries, borage seeds, and valerian root \\
\hline Migraine & Phlegmatic & Lavender, fenugreek seeds, cinnamon, crushed cloves \\
\hline Menorrhagia & $\begin{array}{l}\text { Dry and hot to hot } \\
\text { and dry }\end{array}$ & Liquorice root, barberry \\
\hline Diarrhea & $\begin{array}{l}\text { Cold and } \\
\text { moist/phlegmatic }\end{array}$ & $\begin{array}{l}\text { Ajmo, mint leaves, small piece of fresh ginger boil in water, add honey } \\
\text { and drink three times daily }\end{array}$ \\
\hline $\begin{array}{l}\text { Diabetes } \\
\text { mellitus }\end{array}$ & $\begin{array}{l}\text { Hot and moist to } \\
\text { moist and hot }\end{array}$ & $\begin{array}{l}\text { Ajmo seeds, fenugreek seeds, dried bitter gourd, grind into a fine power, } \\
\text { and then squeeze fresh bitter gourd and mix its juice with power. Put it } \\
\text { in a dry place to be dried. Take three times daily }\end{array}$ \\
\hline Constipation & Cold and dry & $\begin{array}{l}\text { Aloe vera juice, milk thistle, and Senna leaves boiled in water; add } \\
\text { honey and drink at night before go to bed }\end{array}$ \\
\hline
\end{tabular}


Some single drugs are beneficial to reduce complications and are helpful in order to trigger protective mechanisms and to delay catabolic and tissue degrading pathways, which may be due to antioxidant, immuno-modulatory, neuroprotective, hepatoprotective, anti-inflammatory, and vitalizing (iksir-e-badan/rasayana/elixir of life) effects $(46,47)$. This kind of ilaj is helpful in dealing with disease such as those of the liver, peptic ulcers, hypertension, migraines, menorrhagia, diarrhea, diabetes mellitus, and constipation (Table 1).

\section{Conclusions}

While traditional medicine contains many useful, less expensive, and less risky remedies for lots of morbidities, modern medicine makes them appear not beneficial. This study gathers some of these remedies to remind one that it is possible to apply them in our daily lives. The findings show three kinds of treatment based on traditional medicine: regimental therapy, dietotherapy, and drug therapy. Each of these treatments is applicable to special kinds of disease. It is suggested that modern medicine gets more help from the achievements of traditional medicine in the treatment of patients. Besides, it is recommended that more research can be done to elaborate upon these treatments to other and perhaps newly borne diseases.

\section{Acknowledgments:}

We thank the deputy of research and technology of Shahrekord University of Medical Sciences for their support.

\section{Conflict of Interest:}

There is no conflict of interest to be declared.

\section{Authors' contributions:}

All authors contributed to this project and article equally. All authors read and approved the final manuscript.

\section{References:}

1) Lacey AR. The Eleatics and Aristotle on some Problems of Change. Journal of the History of Ideas. 1965; 26(4): 451-68. doi: 10.2307/2708493.

2) Alavi S. Unani medicine in the nineteenth-century public sphere Urdu texts and the Oudh Akhbar. Indian Econ Soc Hist Rev. 2005; 42(1): 101-29. doi: 10.1177/001946460504200104.

3) Stone AD. Avicenna's Theory of Primary Mixture. Arab Sci Philos. 2008; 18(01): 99-119. doi: $10.1017 /$ S0957423908000489.

4) Gruner OC. A treatise on the Canon of medicine of Avicenna: incorporating a translation of the first book. The Classics of Medicine Library. 1930.

5) Mukherjee PK, Wahile A. Integrated approaches towards drug development from Ayurveda and other Indian system of medicines. J ethnopharmacol. 2006; 103(1): 25-35. doi: 10.1016/j.jep.2005.09.024. PMID: 16271286.

6) Subbarayappa BV. The roots of ancient medicine: an historical outline. J Biosci. 2001; 26(2): 135-43. doi: 10.1007/BF02703637. PMID: 11426049.

7) Kazemi S, Asgary S, Moshtaghian J, Rafieian M, Adelnia A, Shamsi F. Liver-protective effects of hydroalcoholic extract of allium hirtifolium boiss. In rats with alloxan-induced diabetes mellitus. ARYA Atheroscler. 2010; 6(1): 11-5. PMID: 22577407, PMCID: PMC3347804.

8) Naghibi ME. The Description of Themes of eighth book of Zakhire Kharazmshahi. congress in commemoration of Sayyid Ismail Jorjani: Academy of Medical Sciences. 2001.

9) Fatma N, Ali T, Naaz S. Historical Dictionary of Nuclear, Biological and Chemical Warfare. Int J res pharm chem.

10) Rahman A, Aslam M. The Unani Concept of Mizaj (temperament) and its Correlation with Biodiversity in Present Epoch-A Review. International Journal of Science and Research (IJSR). 2013; 25: 26.

11) Ahmadieh H, Taei R, Soheilian M, Riazi-Esfahani M, Karkhaneh R, Lashay A, et al. Single-session photodynamic therapy combined with intravitreal bevacizumab and triamcinolone for neovascular agerelated macular degeneration. 2007; 7: 10. doi: 10.1186/1471-2415-7-10. PMID: 17555600, PMCID: PMC1904176.

12) Khaleefathullah S. The Practise of Unani Medicine and Its Research Aspects. India Int Cent Quart. 1991; 123-129.

13) S. J. Zakhire Kharazm Shahi. National Heritage Board. 2000; 361.

14) Sadiduddin G. Al-Mughni fi-Shrah al-Mojezfiltibb. Calcutta, India: The Education Press. 1832. 
15) Chishti GM. The Traditional Healer's Handbook: A Classic Guide to the Medicine of Avicenna. Inner Traditions / Bear \& Co. 1991.

16) Sheehan HE, Hussain SJ. Unani Tibb: History, theory, and contemporary practice in South Asia. Ann Am Acad Pol Soc Sci. 2002; 583(1): 122-35. doi: 10.1177/0002716202583001008.

17) Abu-Asab M, Amri H, Micozzi MS. Avicenna's Medicine: A New Translation of the 11th-Century Canon with Practical Applications for Integrative Health Care. Inner Traditions / Bear \& Co. 2013.

18) Lapham JW. Tot Mizaj: four characters in Uyghur traditions of health, medicine, and longevity: interviewing Hotan County elders in Xinjiang, PRC with Beijing educated Uyghurs 2006.

19) Masawayh HBI, Tabari ZR, Abbas AB, Masihi AS, Ibnsina AA, Tabari AH. Unani medicine. Asian J Tradit Med. 2001; 31.

20) Sina I. Al qanoon fil tib. Lucknow: Mataba Munshi Naval Kishore. 2007; 522.

21) Jabin F. Guiding Tool in Unani Tibb for Maintenance and Preservation of Health: A Review Study. African Journal of Traditional, Complementary and Alternative Medicines. 2011; 8(5Suppl): 140-3. doi: 10.4314/ajtcam.v8i5S.7.

22) Yaser Abdelhamid ND. Unani Medical Theory in Principle, Part 2-The Vis Medicatrix Naturae. Integr Med. 2012; 11(4): 26.

23) McMahon CE. The role of imagination in the disease process: pre-Cartesian history (the role of imagination in the disease process). Psychol med. 1976; 6(2): 179-84. doi: 10.1017/S0033291700013738. PMID: 794894.

24) Sharma H, Chandola HM, Singh G, Basisht G. Utilization of Ayurveda in health care: an approach for prevention, health promotion, and treatment of disease. Part 1--Ayurveda, the science of life. J Altern Complement Med. 2007; 13(9): 1011-9. doi: 10.1089/acm.2007.7017-A. PMID: 18047449.

25) Rahman SZ, Khan RA, Latif A. Importance of pharmacovigilance in Unani system of medicine. Indian $j$ pharmacol. 2008; 40(7): 17-20.

26) Bhika R, Haq HMA. Tibb traditional roots of medicine in modern routes to health. Mountain of Light S.A. 2000.

27) Zaman R, Basar SN, Farah SA. Dieto Therapy in Unani System of Medicine. Int J Pharm Biol Sci. 2013; 3(4): 1035-9.

28) Rafiean M, Khajegir A, kiani S. The Association between Dystemperament and Prevention of Diseases: A Systematic Review. J Clin Diagn Res. 2016; 10(9): YE01-YE06. doi: 10.7860/JCDR/2016/19023.8511.

29) Lone AH, Ahmad T, Anwar M, Sofi G, Imam H, Habib S. Perception of health promotion in Unani herbal medicine. J Herb Med. 2012; 2(1): 1-5. doi: 10.1016/j.hermed.2012.02.003.

30) Ahmad S, Mannan A, Hasan I. Evaluation of Therapeutic Effect of a Polyherbal Formulation in Patients of Asthma with different kind of Temperament. Glob J Med Res. 2013; 13(1).

31) Smith RD. Avicenna and the Canon of Medicine: a millennial tribute. West J Med. 1980; 133(4): 367-70. PMID: 7051568, PMCID: PMC1272342.

32) Masoudi M, Miraj S, Rafieian-Kopaei M. Comparison of the Effects of Myrtus Communis L, Berberis Vulgaris and Metronidazole Vaginal Gel alone for the Treatment of Bacterial Vaginosis. J Clin Diagn Res. 2016; 10(3): QC04-7. doi: 10.7860/JCDR/2016/17211.7392. PMID: 27134945, PMCID: PMC4843330.

33) Baghbahadorani FK, Miraj S. The impact of Silymarin on improvement of platelet abnormalities in patients with severe preeclampsia. Electron Physician. 2016; 8(5): 2436. doi: 10.19082/2436.

34) Masoudi M, Miraj S. A comparison of the efficacy of metronidazole vaginal gel and Myrtus (Myrtus communis) extract combination and metronidazole vaginal gel alone in the treatment of recurrent bacterial vaginosis. Avicenna J Phytomed. 2016; 1-7. doi: 10.22038/ajp.2016.7286.

35) Sha'bani N, Miraj S, Rafieian-kohpayei M, Namjoo AR. Survey of the detoxification effect of green tea extract on the reproductive system in rats exposed to lead acetate. Adv Biomed Res. 2015; 4: 155. doi: 10.4103/2277-9175.161582. PMID: 26380240, PMCID: PMC4550946.

36) Miraj S, Kiani S. A scientific correlation between dystemprament in Unani medicine and diseases. electron physician. 2016; 8(9).

37) Miraj S, Kiani S. Menstrual diseases as stated in canon fil-Tibb. Der Pharmacia Lettre. 2016; 8(6): 261-8.

38) Seyyedi F, Rafiean M, Miraj S. Comparison of the Effects of Vaginal Royal Jelly and Vaginal Estrogen on Quality of Life, Sexual and Urinary Function in Postmenopausal Women. J Clin Diagn Res. 2016; 10(5). doi: 10.7860/JCDR/2016/17844.7715.

39) Eftekhar M, Miraj S. The in vitro fertilization outcome and luteal phase GnRH antagonist administration. Iran J Reprod Med. 2015; 40. 
40) Taghizade Mortezaee F, Tabatabaiefar MA, Hashemzadeh Chaleshtori M, Miraj S. Lack of Association between ESR1 and CYP1A1 Gene Polymorphisms and Susceptibility to Uterine Leiomyoma in Female Patients of Iranian Descent. Cell J. 2014; 16(2): 225-30. PMID: 24567938, PMCID: PMC4072073.

41) Davar R, Miraj S, Mojtahedi MF. Effect of adding human chorionic gonadotropin to frozen thawed embryo transfer cycles with history of thin endometrium. Int J Reprod Biomed. 2016; 14(1): 53-6. PMID: 27141549, PMCID: PMC4837920.

42) Alam MA, Nayab M, Azeez A, Quamri MA, Ansari AN. Muscular dystrophy (Istirkha) and its management through Unani Medicine: a review. Int J Herb Med. 2014; 2(4): 1-5.

43) Grant M. Galen on food and diet. Psychology Press. 2000.

44) Khan NA. Unani Concept of Drug Temperament and its Relevance to Efficacy of Single Unani Drugs. Tradit Syst Med. 2006; 25.

45) Ibn Sina. In: Shah Hosseini G, editor. English translation In: Mazhar H Shah. 1. Karachi:1996. p: 359, 25, $185,8,361,194,372$.

46) Razi M. Al-havi. International Academy of Medical Sciences, Tehran. 2005.

47) Rushd I. Kitab Al-Kulliyat. Central Council for Research in Unani Medicine Ministry of Health \& Family Welfare Govt of India New Delhi. 1987; 342-70. 